\title{
Digital game-based learning and technology-enhanced learning for theological education
}

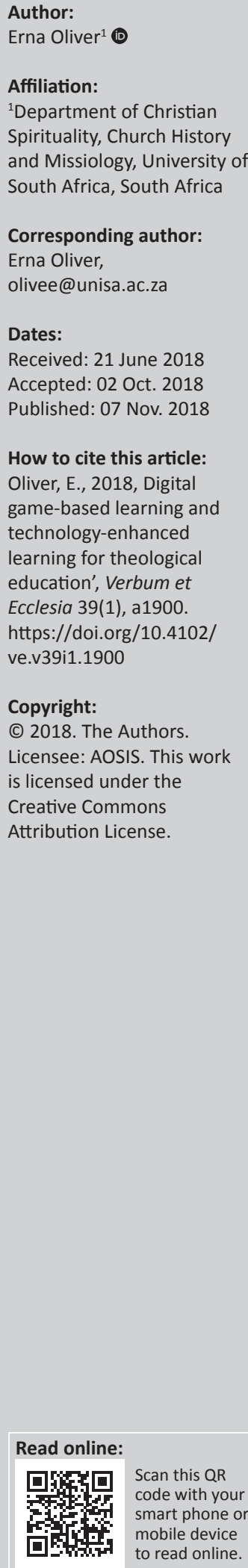

Digital game-based learning (DGBL) - sometimes loosely referred to as gaming - for higher education has not really found its feet in South Africa as an innovative or alternative tool to enhance the impact of education. Internationally, it is implemented at some institutions of higher education and also in the corporate training world. Technology-enhanced learning ([digital] TEL) is also not yet fully implemented in the higher education environment in South Africa, as many institutions are still bound to the Gutenberg era and are therefore still mainly paper-based. The research is linked to constructivism and is conducted from a South African perspective. The aim is to provide a broader context for DGBL within the environment of TEL and to present it as an additional and innovative aid to provide effective education (that includes student-centred teaching, blended learning and transformative assessment) opportunities for students in theology.

Intradisciplinary and/or interdisciplinary implications: Digital game-based learning as a part of TEL can be implemented in teaching all aspects of theology through the blended learning approach (that includes time, space, activity and media, formal, informal and nonformal learning and prior learning and experience) providing possibilities for active learning and constructing knowledge.

Technology has augmented the cognitive power of our brains to such an extent that being deprived of one's smartphone/laptop, feels like one has lost one's own cognitive capacity. (cf. Kok 2009:3)

\section{Introduction}

Ponder for a moment on this scenario on the use of technology in day-to-day life: In an international T20 cricket game played in 2018 in India, the South African opening bowler bowls a ball at the opening batsman of India at a speed of more than $140 \mathrm{~km} / \mathrm{h}$, and the ball hits the batsman low on the front leg. The referee, watching the situation, hears the cry of the bowler for leg before wicket (LBW). The referee wonders if this bowler did not overstep his crease (but it happened too quickly for the human eye to look at that and to look at the ball flying past him) and added to that tries to replay the whole action in his mind's eye to the best of his ability to make a decision on LBW or not - and then decides that the batsman is out. As there are no reviews in a T20 game, the batsman has to walk. While he is walking off the pitch, the spectators are conveniently (but very angrily) watching a replay of the bowling action - in slow motion on the big screen, and with the help of Hawk-Eye technology, clearly see that the bowler overstepped his crease and that the ball would have missed the stumps - therefore, the batsman is not out. This decision of the referee has turned the whole game in favour of the bowling team. Despite the technological support that is available, the referee has to make a decision without the 21st-century technological support, about something that happened (too quickly) before his eyes during the past couple of seconds. We are quick to criticise the International Cricket Board for not utilising available technologies, but in fact we as lecturers are often doing exactly the same when it comes to education - negatively affecting both the lecturers and the future of the current generation of students in our country. ${ }^{1}$

Although Van Eck (2015:25), based in the United States (US), postulates that the time for proselytising is over - meaning that 'everybody ${ }^{2 \prime}$ is convinced that digital game-based learning

1.For a critical review of the literature on TEL and DGBL between 2005 and 2010 , see Kirkwood and Price 2014; see also Oliver (2017) for a more positive review up to 2016. For a systematic literature review that games have on higher education, see Vlachopoulos and Makri (2017). For a thorough literature review only on (D)GBL between 2001 and 2010, see Hwang and Wu (2012), as well as Hwang and Tsai (2011)

2. His findings are based on a $19 \%$ annual growth of online courses at higher education level in the USA between 2002 and 2008 (cf. Hess \& Gunther 2013:3 of 22); a 10\% growth between 2009 and 2010 (Allen \& Seaman 2011); and an 11.3\% growth in 2015 (Babson Survey Research Group 2017). 
$(\mathrm{DGBL})^{3}$ is part of the future of education or learning ${ }^{4}$ - this concept still needs to establish itself in most institutions of higher education in South Africa. The aim of this article is to discuss and advance the use of DGBL within the higher education environment and against the backdrop of technology-enhanced learning (TEL). After a short summary on TEL and an explanation of DGBL, examples are given to provide evidence of how lecturers successfully implemented DGBL in higher education. Finally, South African lecturers (especially theologians) are encouraged to embrace and seek opportunities to implement DGBL for teaching difficult languages, threshold concepts and skills in theology. Digital game-based learning can serve as practical training platforms for theology students to experiment, gain experience, develop skills (including critical thinking skills, digital literacy skills, language competency skills and life skills) and interact with others (peers, lecturers, etc.) in a safe environment.

\section{Methodology}

The study is conducted against the backdrop of constructivism that became popular during the second half of the previous century (cf. Attard 2010:8) where real-life and personal applications together with contextual learning are the focus points. Learning takes place when a person's experience does not align with his or her cognitive schemes, thus creating a cognitive disequilibrium, resulting in adjusting and the creation of new knowledge when a re-equilibrium is formed (MacLellan \& Soden 2004:254). Students are 'active agent[s] in the process of knowledge acquisition' (Bada 2015:66), updating their accommodation (i.e. their personal mental capacity), while constructing new meaning through assimilation with prior knowledge (cf. Bada 2015:66-67).

\section{Technology-enhanced learning}

Walker, Voce and Ahmed (2012) define TEL as:

any online facility or system that directly supports learning and teaching. This may include a formal VLE, ${ }^{5}$ an institutional intranet that has a learning and teaching component, a system that has been developed in house or a particular suite of specific individual tools. (p. 1)

The definition of Gordon $(2014)^{6}$ adds to this:

Technology-enhanced-learning ... considers the use of Information Communication and Technology (ICT) in its widest sense to

3.Van Eck (2015:14) refers to it as digital game-based learning to distinguish it from nalogue games such as Monopoly and other car based to focus on the fact that it is not a normal game, and it is game-based learning to indicate that this game is in service of education and not advertising. The shortened form of this term is GBL (game-based learning), used by many scholars. Therefore, GBL will also be used in this article when scholars refer to it in that way.

4.Already in 2006, Van Eck claimed that all the prejudices against DGBL have been silenced, because of three factors (Van Eck 2006:1):

- First was the multitude of essays, articles and books published on the topic.

- Second was the 'Net generation', also called 'digital natives' (in 2015, Van Eck has decided not to use this term anymore, because of the fact that 'digital natives' students born after 1990 - are not all 'addicted' to games, as he thought they would be. In fact, $23 \%$ of the 'natives' are only playing one hour of games in week [Van Eck 2015:14]), who disengaged themselves from traditional teaching week [Van Eck 2015:14]), who disengaged themselves from traditional teaching López are still using this term (Cózar-Gutiérrez \& Sáez-López 2016:2).

- Third was the fact that games became increasingly popular.

5.Virtual learning environment.

6.Gordon (2014:4) equates TEL to e-learning, while Kirkwood and Price state that TEL subsumes e-learning. support and improve the learning experience ... whether that learning is local (on campus) or remote (at home or in the workplace). (pp. 3-4)

He adds:

[T] echnology can enable new approaches as to how learning is delivered and assessed, and can make certain pedagogic approaches viable and scalable when considered for higher education that otherwise would not be. (Gordon 2014:3)

The internal strategies that influence the institution of TEL are teaching, learning and assessment (Walker et al. 2012:2, 11). The primary drivers for TEL are enhancing the quality of teaching and learning, meeting student expectations and improving their access to learning off-campus.

The focal point of TEL is the enhancement of the learning process through the use of technology, 'where technology plays a significant supportive role' (Goodyear \& Retalis 2010:vii). Technology must support flexible pedagogies and balance the need for the lecturer to supply high-quality teaching to the students, giving them ample space to do significant research on their own (Gordon 2014:4). The use of technology in service of education must be driven by pedagogical, research and community-directed needs and not by technological determinism (Pariser 2011). Put simply, TEL is the utilising of technology to support and enhance the learning practices of people (cf. Kok 2009:3). If this is not the case, it gives rise to 'boring games and drill-and-kill learning' (Van Eck 2006:3). There must therefore be a positive synergy between pedagogy and technology.

The technology must be adapted and developed to support the pedagogical approach. It should be an interdisciplinary approach, requiring a collaboration between lecturers, software and technology developers, also involving students, 'all with a shared intent to move ideas across boundaries and to explore new approaches to learning and teaching' (TELRP 2013:7). Laurillard (2002) refers to TEL in this context as 'education as a conversation', meaning that it is interactive in toto. The aim of TEL is to provide control and active participation to its users: If students are 'involved, participating, engaged, and interacting with the material, then learning is maximised' (Dror 2007:5; cf. also Cardenal 2016), because it:

activates and correctly taps into the cognitive mechanisms of learning, such as attention, depth of processing, and other cognitive elements of learning. TEL enables us to shift from merely exposing the learners to the material, to transforming the learning environment. (Dror 2007:5; cf. Dror 2010:79)

Successful learning can take place if the learning tool conforms to both the learning objectives and the 'architecture of the mind' (Dror 2007:4; cf. Dror 2005). Dror (2007) explains:

[T]his means training must take into account constraints on information processing capacity. Information during learning need not be reduced to fit the limits of the cognitive system, rather the information must be conveyed in ways in which the system can easily acquire and store it. This can be accomplished by using the correct mental representations and engaging the 
cognitive system on its own terms. Doing so will not only enable quick and efficient acquisition, but the knowledge gained will be better remembered and will have an impact on behaviour. (p. 4)

Technology-enhanced learning encompasses terms like 'educational technology', 'computer-aided learning', 'ICT' and even 'e-learning' - Kirkwood and Price (2014:1) correctly argue that it subsumes e-learning. It comprises 'everything' that is technology-enhanced and has a clear connection with teaching and learning - found in programmes like Blackboard Learn, Moodle and Socrative, or on YouTube, massive open online cources (MOOCs), open educational resources (OERs), or even a blog, where an (interactive) virtual learning environment (VLE) is created. It utilises different types of technology in order to find more engaging and beneficial ways to teach, learn and assess. Technology-enhanced learning could also include social media as learning and teaching tools. It is a complex system, involving 'communities, technologies and practices that are informed by pedagogy' (TELRP 2013:5; cf. Kirkwood \& Price 2014:1).

Although TEL cannot be ignored anymore (cf. Lin \& Tu 2012), many lecturers display a 'variable but understandable resistance to innovations' (TELRP 2013:14, here referring to the UK), regarding educational and training practices. The key reasons for this resistance are threefold (GLC 2015):

- Training: Lecturers are trained experts in their discipline, but not in research-based pedagogies or educational technologies. ${ }^{7}$

- Contextualisation: Technology-enhanced learning requires from lecturers to adapt past research results to the current context; initially, there is a chance to fail, but this should not dissuade one from trying again.

- Time constrains: Lecturers complain about the initial time needed for the creation of these activities, although these are key to the development of effective instruction. (p. 3)

Personal experience and interaction with colleagues during training sessions on TEL brought the author to the conclusion that this resistance is often backed by the following negative drivers:

- Lecturers do not know what TEL really is and what it can accomplish.

- Lecturers are confusing e-learning with the use of the Internet to deliver course material to the students.

- Lecturers are not aware that most of their students prefer the use of technology to enhance learning.

- Lecturers are reluctant to spend time to develop TEL tools and content because it is not fully taken into consideration in their annual assessment of key performance areas.

- Lecturers are unaware of the possible positive impact TEL could have on their teaching results.

It is important to take note of the resistance to implementing TEL. However, higher education in South Africa must move

7.This implies that educators need 'proper training and professional development' in
order to be as effective as the tools that they are using (Spector et al. 2016:65; order to be as effective as the
cf. Spector \& Anderson 2000). forward, and one way to not only break through some of the resistance but also advocate for the advantages of using technology as an important supporting tool in education is to complement and expand TEL through the use of DGBL.

\section{Digital game-based learning}

Gaming - or playing games - is one of the most natural ways of learning (cf. Sung \& Hwang 2013:44). Kumar explains (in Pappas 2015): 'We, human beings, are natural "gamers"! ... This, as we know, is basically because games are fun, engaging, challenging, and, above all, motivating'. The immediate advantage is that knowledge retention is much higher when playing a game (here specifically focused on an educational game) than being a passive learner (cf. Brom, Preuss \& Klement 2011:1971-1988). ${ }^{8}$

At the start of the century, Prensky published a book, Digital game-based learning, in which he argued that the combination of games and education could advance the motivation of students and also help them to study in an interactive way (Prensky 2001:4). A few years later, research indicated that DGBL is more effective than passive learning to acquire knowledge (cf. Cagiltay 2007:405-415; Papastergiou 2009: 1-12; Tüzün et al. 2009:68-77). Digital game-based learning also advances the learning interests of students and motivates them to study more and harder (Burguillo 2010:566-575; Dickey 2011:456-469; Harris \& Reid 2005; Hwang et al. 2012:623-638; Liu \& Chu 2010:630-643). Research conducted by scholars like Huang, Huang and Tschopp (2010:789-797), Ariffin, Oxley and Sulaiman' (2014:20-27), Woo (2014: 291-307), as well as Clark, Tanner-Smith and Killingsworth (2016) and Nadolny and Halabi (2016:51-72) in the second decade of the 21st century proved Prensky correct.

Digital game-based learning, ${ }^{10}$ within the environment of TEL, refers to the use of digital games with educational value, that is, games for learning and educational purposes (cf. Tang, Hanneghan \& El-Rhalibi 2009:3), and must be distinguished from gamification. ${ }^{11}$ Added to this, not every digital game

8.A further advantage, for some students, is the so-called one-to-one factor - having al the information on one's own mobile phone, not sharing it with others, as was the case in the past where students had to share computers (cf. Chan et al. 2006:3-29).

9.These scholars have specifically indicated that ethnicity, culture and language have a significant influence on the success rate of gaming (Ariffin et al. 2014:22-23), a topic that should be investigated more in future, especially in a country like South Africa that has a clear diversity on each of these levels.

10.In 2013, Boeker et al. referred to DGBL as 'game-based e-learning'.

11.Van Eck (2015:21) wrongfully refers to gamification as a 'new DGBL approach', where game mechanics are implemented in typical classroom processes. Gamification helps learning processes, but it is not training itself. It uses game mechanics to engage students in the training efforts. Some of the gamification techniques used are competition, stories, achievements, levels, stages and rewards (cf. Wiggins \& Simkowski 2014:2050), and these are not only done within a digital environment. The purpose is to increase motivation, making the training fun engaging students and improving completion rates (Gamelearn 2014). Gordon (2014) seems to apply most of the characteristics of DGBL to gamification, also putting the latter within a virtual environment:

The use of game techniques (especially game mechanics) to encourage and motivate activities can be especially relevant to learning. Online worlds provide a virtual environment for learning, with the game models of players logging in playing and interacting, making progress and then logging off matching some of the needs of flexible learning. Thus gamification supports new pedagogic approaches that allow for flexibility. (p. 8)

Gamification can be implemented without any 'digital' devices, while DGBL can only be performed within a digital environment - 'learning through games' or the 'use of the inherent design of most games ... to learn' (Teachthought 2014). 
belongs to the environment of DGBL. A lecturer should therefore ensure that the prescribed game for the students complies with all the standards and requirements of a good educational game and that it serves to assist in teaching, learning or assessment of course content and the required outcomes. The lecturer must see to it that the game is interesting and set at the correct difficulty level, always with the advantages of scaffolding in mind (cf. Rosenschine \& Meister 1992:26-33). It must be suitable (small enough) for the students' devices such as smartphones, tablets and laptops.

With DGBL, a student is empowered to learn academic content through playing a game. Digital game-based learning should form part of the 'pedagogical approaches' of TEL, as the learning process requires a concept to be learned, the ability to put the concept into practice and the possibility to receive personalised feedback as to visualise the results of the student's (and lecturer's) performance. Digital game-based learning happens when the game itself is teaching the student. The game ensures that experiential learning is taking place (Gamelearn 2014; cf. also D2L 2016). It is therefore used in service of learning and aimed at teaching a discrete skill or specific learning outcome (cf. Taljaard 2015). Cardenal (2016) refers to specific skills like creativity, cooperation, communication and critical thinking. Rather than being a complete pedagogical system, DGBL as a learning process (1) turns students into problem solvers; (2) fosters student design thinking; (3) allows students to engage in friendly competitions; and (4) helps students to learn how to analyse multimodalities.

Dror (2010) identifies three C's of learning, namely control, challenge and commitment. Ebner and Holzinger (2007:875) add another $C$, namely curiosity. These C's need to be activated during the process of DGBL:

- Control: The traditional way in which study guides are constructed takes control away from the students, urging them to passively follow the dictated course or programme. Technology-enhanced learning can be implemented to pass a greater portion of control to students. Increased control means increased responsibility, where students must be advised, guided and supported to obtain the acquired knowledge and skills at their own pace. Digital game-based learning is an effective tool to put control in the hands of students, allowing them to monitor their own progress and also to identify where they need support, while having access to immediate feedback and an option for the lecturer to intervene.

- Challenge: Cognitive stretching, problem-solving and acquiring skills are essential parts of learning. The students experience accomplishment that will make them feel proud of their achievements (p. 83). Through DGBL, students get the opportunity to think issues through, reflect on them and seek solutions in an environment where it is safe to fail (cf. Rapti 2013:96). Digital gamebased learning can make these learning processes fun, challenging and interactive. Gaming can make a 'dead horse' a 'racing horse' (p. 83).
Dror (2010) refers to gaming as a good example of TEL:

[V]ia a gaming framework ... learning can be made challenging not only by modifying how the material is presented and the role of the learners, but also by providing clear signs, measurements, and feedback about the learners' advancement and progression. These should be clearly laid out throughout the learning game so the learners can see how well they are doing. (p. 83)

Here immediate feedback and a clear measurement of success are key.

- Commitment: Control and challenge are huge contributing factors to commitment. In this regard, DGBL can play a vital role, with all its extras like experience points (XP) and badges, which act as natural motivational boosters.

- Curiosity: Digital game-based learning can stimulate curiosity and encourage exploration and risk-taking, again within a safe-to-fail environment. This implies that the DGBL tool should be flexible and cater for various levels of knowledge, skills and abilities of the users (cf. Dickey 2011:456-469; Malone 1980:162-169).

Digital game-based learning supports 'powerful learning strategies such as situated learning, authentic environments, and optimized challenge and support (scaffolding)' (Van Eck 2015:14). It also 'promotes general educational skills such as spelling and reading .... and a wide range of cognitive abilities including spatial visualization, divided attention, and knowledge mapping' (Van Eck 2015:15). It further enhances 'critical thinking, problem-solving, collaboration, effective communication, motivation, persistence, or learning to learn' (Van Eck 2015:15). According to Dror (2010:80), '[t]his new level of learning is more sophisticated, superior, and can achieve short and long-term objectives that otherwise are not possible'. It brings about 'engagement, involvement, participation, and interaction. These are all critical ingredients for achieving effective and efficient learning because they maximise many cognitive mechanisms' (Dror 2010:84). To make DGBL effective, these elements should therefore be present in this kind of learning.

Critics have the conviction that games would only cover lower-level intellectual skills. However, educational games should take place within a meaningful and relevant context where a student's learning process is directly related to the environment, being applied and practised within that context. When learning occurs in 'meaningful and relevant contexts', it is 'more effective than learning that occurs ... with most formal instruction' (Van Eck 2006:4). This is not only applicable to lower-level thinking skills, but to all learning and pedagogical skills.

Two myths about gaming within DGBL must be addressed (See 2016):

- It makes learning easier: Learning is not easy and the use of technology does not ease the pain. Using DGBL might make it seems easier because students spend more time on engaging with the content, exploring possibilities, and participating, causing them to experience the learning 
activity as more satisfactory, and therefore, in their view, easier than learning in traditional ways.

- Games are fun: This is a sweeping statement and dangerous when working with DGBL where games are only fun when they are well-designed, purpose- and outcomesdriven, and developed to cater for the cognitive levels and skills of the users while also providing an entertaining and 'fun' component.

Next, some examples of the implementation of DGBL in higher education serve to illustrate the benefits and possibilities of using DGBL as a valuable educational tool.

\section{Examples of digital game-based learning in higher education}

Publications on the use of DGBL in an educational environment have lately escalated to such an extent that it is difficult to keep up with the most recent trends. The 'first' DGBL game was launched in the late 1950s when the Massachusetts Institute of Technology (MIT) developed the Beer Game (MIT 2017) - it was then a table top game and was later developed to be an online game (Dizikes 2013) - to help students understand how the patterns that are created in 'production chains, logistics chains and customer chains sometimes yield unexpected and undesired results' (Chang, Peng \& Chao 2010:320).

Kiili created a model that would successfully integrate educational theory and game design aspects. This model stressed the fact that students need immediate feedback. The model only served as a link between educational theory and game design, and it did not provide the means to a whole game design project (Kiili 2005:13). He presented an experiential gaming model that stresses the 'importance of designing and balancing challenges in order to generate an optimal learning experience for players' (Kiili 2005:13). This is a noteworthy project, as it made more and more people aware of the need to gamify. The next logical step would be to create games that would answer the call for educating the students in a fun-like motivational way real DGBL.

In 2007, Ebner and Holzinger decided to implement DGBL for their seventh-semester Civil Engineering students. As parts of the subject were 'routine and boring' (Ebner \& Holzinger 2007:874), they decided to give their students an online game - Internal Force Master (IFM) - to play. In this game, the students had to choose the right engineering solution to win. With the win-lose component built in the game, their aim was to boost their students' motivation, while having fun. Repeated playing of the game would also lead to easier and more in-depth learning. The purpose of the game was to help the students especially in the field of static determinate systems to make the right decisions about the calculation of the internal forces based on the Theory of Structures. The outcomes were positive (Ebner \& Holzinger 2007:874).
Also in 2007, Chang, Peng and Chao developed a game called SIMPLE (Simulation of Production and Logistics Environment) in 'three decision-science courses in industrial engineering' (Chang et al. 2010:319). The problem they wanted to address was that lecturers, on the one hand, find it difficult to help students to 'develop decision-making skills for complex, ill-defined practical situations' (Chang et al. 2010:319), while the students, on the other hand, have difficulty to apply theoretical knowledge in resolving illdefined problems, ending up in creating more problems. This game involved four online players in a supply-chain environment, where the students needed to not only co-operate but also compete with their team members for the best performance. The developers intensely linked pedagogy to the game and effectively addressed strategies for integrating the game into three of their courses. The outcome was positive.

In 2013, Boeker et al. wrote about an experiment they did in 2008-2009 with third-year medical (urology) students, using an educational adventure game, called Uro-Island. They used two groups, one playing the game, and the other doing conventional training, called the 'script group' (Boeker et al. 2013; cf. fn. 3). The results clearly showed that the students playing the game scored better marks on the cognitive knowledge test, while showing more positive attitudes towards the recent learning experience.

In 2014, Ross, Fitzgerald and Rhodes reported about a game called Space Tug Skirmish (STS), which was designed (also by MIT) for use as a 'teaching tool for systems engineering core concepts' (Ross et al. 2014:430-440). As systems engineering is a complex field of study, they developed this digital multi-player card game to help students master the basic concepts of the 'design and operation of complex systems in an uncertain environment' (Ross et al. 2014:431). They discovered that their students played the game for hours and benefited much from it.

Also in 2014, Kikot et al. (2014:229-241) reported on a business programme being developed at the University of Algarve(Portugal), called Cesim SimBrand, used for marketing simulation. Their expected outcome was that the participants should 'fully comprehend the different parts of the marketing decision-making process, their relationship with each other, and their impact on the company's overall results' (Kikot et al. 2014:231). Added to that the participants would gain 'invaluable experience in teamwork and problem solving' (Kikot et al. 2014:231). Their students 'revealed positive experiences and better learning engagement' (Kikot et al. 2014:239).

Cubic Global Defence (2015) combined the best features of computer-based training and on-the-job training with the focus, attention and fun of video games in a 3D (threedimensional) environment. In this game, the students were taught by a virtual instructor, applying to mechanical, medical and public safety job training, including high-risk 
jobs such as fire-fighting, using virtual training environments. This is an example of the combination of theory and practice in one game.

Cózar-Gutiérrez and Sáez-López (2016) refer to a game, MinecraftEdu, played by second-year Master's Degree students in Primary Education in the subject 'Social Sciences: History and Teaching' at Castilla-La Mancha University in Spain. The game was all about training future teachers. After playing the game, the students had to answer a questionnaire. The feedback on the game was very positive, as the students considered the game essential for training future teachers, indicating that active learning took place and that they had fun.

Other games that have already been used in higher education, mostly in residential universities, are Civilization, CSI, Age of Empires II, The Sims 2, Age of Mythology and SimCity 4 (cf. Van Eck 2006:9).

Many scholars, when referring to DGBL, do not indicate whether the students should play the games on their own ('solitary') or with other students ('collaborative'). Chen, Wang and Lin (2015:237-248) compared these two modes of play in their study and interestingly discovered that the outcomes were similar.

In the light of the positive outcomes referred to above, the challenge is directed to lecturers and management of higher education institutions to implement DGBL in an effort to enhance the educational process.

\section{Digital game-based learning for theology students}

The suggestion here is to implement TEL and DGBL within theology. Why theology? Theology played a major role in the foundation of many universities through the ages, like the University of Bologna in 1088 (cf. Haskins 1957; Rashdall 1936), which developed from a monastery and cathedral schools, and the university of Paris in 1150, which was a product of a cathedral school (cf. Boeree 2000). In the 13th century, Thomas Aquinas, in his Summa Theologica (Prologue, Art 1 Objection 2 \& Art 5 - reply to Objection 2), referring to Aristotle's Metaphysics (Book 1 Chapter 2 - Taylor 1801:6), regarded other sciences as the handmaidens of this one [theology]' (Fathers of the English Dominican Province 2006:767, 774), therefore suggesting that theology was the ultimate of all sciences. Although theology is often not regarded as the 'queen of sciences' anymore (cf. Loughlin 2009:221-240), this article takes the premise of Tracy (2002:1322) who puts theology at the epicentre of his three so-called 'publics' or spheres, namely society, academia and church. This implies that theologians have an important role to play in society. Besides from being a leading influence in society that can once again bring positive change to the South African context, theology has relatively low student numbers which make experimenting and implementation of DGBL easier while providing a safe-to-fail environment for learning.
With this in mind, implementing DGBL in theology should have the three 'publics' of Tracy in mind and add to it the premise of Richardson (2005:556-557), who used the prefix 'inter' as a philosophical framework for theology. Referring to the future of theology in South Africa, he argued that it will flourish when becoming inter-denominational, interfaith, inter-cultural, international, interdisciplinary and interactive. The two models of Tracy and Richardson, being applied in DGBL, can supply students with a myriad of information and practice opportunities to widen their perspectives and worldviews and have a positive effect on their actions and behaviour when dealing with theological, social and academic issues after practising and developing the needed knowledge and skills in the gaming environment. Theology students need practice in solving authentic and real-life problems that include much more than only spiritual or faith-related problems. They need to develop innovative, design and critical thinking skills as well as the ability to collaborate and communicate effectively as theologians. Game-based learning could provide the platform for accomplishing specific learning outcomes and threshold concepts. Resulting from such DGBL activities, students should be encouraged to become change agents in 21stcentury South Africa.

When discussing how this should be done, lecturers must take note of the following: DGBL utilises TEL to effectively present parts of curricula to students and not an entire course. Lecturers must first identify the difficult-to-explain parts, thresholds and learning elements that are not really interesting but important and fundamental in the specific course (cf. McGonigal 2011; Zichermann \& Linder 2010) as well as the most important outcomes of the course, as this is where DGBL could be implemented. These must form the core of the content included in the game. This is applicable from the first year of study onward, where students have to learn difficult languages like Greek and Hebrew, as well as Latin and German. Although there are already applications ('apps') and digital courses available to assist students, they are not really gamified and therefore lack the four important C's of DGBL that would enhance successful outcomes.

Developing DGBL is teamwork and the team should include:

- Lecturers - for identifying and compiling the content that should be used.

- A game designer - for identifying existing games that can be used, finding the best mould in which a game should fit or creating a new game (which could be costly and time-consuming).

- A group of students - to assist the lecturers and review the game and content designed by the game designer (cf. Attard 2010:19-20).

- Management - for approving the process and securing funding.

- A very enthusiastic coordinator displaying the four C's (control, challenge, commitment and curiosity) in 
abundance - to keep the group together, to motivate everybody and to make sure that every part of the process runs according to schedule.

It is possible to use an existing game as a basic tool and altering the content to save on development time and costs. A single gaming tool can also be used for different theological disciplines and courses. Maybe the biggest advantage of implementing DGBL is that it can be used as an alternative assessment method to replace tests, exams and venuebased assessments. The added bonus in this case is less marking to be done, as the game can automatically record scores and progress. The implication for future research is that prototype games for use in theology education should be developed and implemented to ensure that students enjoy the advantages of DGBL and TEL.

\section{Conclusion}

This article provides an overview of DGBL from a South African perspective and serves as an open invitation to South Africans to participate (more) in this worldwide shift within education. Technology-enhanced learning provides opportunities for lecturers to use an ever-increasing number of innovations to enhance education. Although DGBL is not making the educational process easier (learning is normally not easy) and does not always equal fun, it does open more and additional off-campus learning opportunities. Not only does it provide a natural way of learning important skills and competencies through a digital game designed to include specific educational outcomes, it also provides active learning opportunities through practicing to solve real-life problems in a safe environment (that is important for the humanities) and encourage collaboration. Digital game-based learning can be implemented into the whole spectrum of theology education and provide much needed skills and knowledge that can be transferred by the theologians into addressing problems and needs in society, academia and church.

Although TEL is winning ground in the higher education environment in South Africa, DGBL is not a standard practice yet. One of the reasons could be that the terms are confusing to lecturers. Added to this, lecturers are not yet prepared to invest large amounts of time doing research on TEL and DGBL. This article assists by explaining the concepts of TEL and DGBL and by showing through examples that DGBL produces constant positive results in the educational environment. It is also clear that lecturers can use existing game platforms and templates to create unique and often fun-filled teaching options, learning opportunities and assessment tasks.

Lecturers in South Africa - with special reference to those in theology - are encouraged to contribute to the research on, experiment with and implement TEL and DGBL as part of their curriculum development. A paradigm shift away from the structured, passive learning model is needed towards an interactive model where we can engage our students to become active participants in the learning process and make them knowledgeable and lifelong learners by using technology to enhance the educational process. Theology serves as a good environment to activate this paradigm shift.

\section{Acknowledgements Competing interests}

The author declares that she has no financial or personal relationships that may have inappropriately influenced her in writing this article.

\section{References}

Allen, I.E. \& Seaman, J., 2011, Going the distance: Online education in the United States, Babson Survey Research Group, viewed 06 December 2017, from http:// www.onlinelearningsurvey.com/reports/goingthedistance.pdf

Ariffin, M.M., Oxley, A. \& Sulaiman, S., 2014, 'Evaluating game-based learning effectiveness in higher education', Procedia - Social and Behavioral Sciences 123, 20-27. https://doi.org/10.1016/j.sbspro.2014.01.1393

Attard, A. (ed.), 2010, Student centered learning: An insight into theory and practice, Partos Timisoara, Bucharest.

Babson Survey Research Group, 2017, Higher education reports, viewed 06 December 2017, from https://www.onlinelearningsurvey.com/highered.html.

Bada, S.O., 2015, 'Constructivism learning theory: A paradigm for teaching and learning', Journal of Research \& Method in Education 5(6), 66-70.

Boeker, M., Andel, P., Vach, W. \& Frankenschmidt, A., 2013, 'Game-based e-learning is more effective than a conventional instructional method: A randomized controlled trial with third-year medical students', PLoS One 8(12), e82328. https://doi. org/10.1371/journal.pone.0082328

Boeree, C.G., 2000, The middle ages, viewed 01 January 2018, from http://webspace. ship.edu/cgboer/middleages.html.

Brom, C., Preuss, M. \& Klement, D., 2011, 'Are educational computer micro-games engaging and effective for knowledge acquisition at high-schools? A quasiexperimental study', Computers \& Education 57(3), 1971-1988. https://doi org/10.1016/j.compedu.2011.04.007

Burguillo, J.C., 2010, 'Using game theory and competition-based learning to stimulate student motivation and performance', Computers \& Education 55(2), 566-575. https://doi.org/10.1016/j.compedu.2010.02.018

Cagiltay, N.E., 2007, 'Teaching software engineering by means of computer-game development: Challenges and opportunities', British Journal of Educational Technology 38(3), 405-415. https://doi.org/10.1111/j.1467-8535.2007.00705.x

Cardenal, L., 2016, 'Digital games based learning', YouTube video, viewed 07 November 2017, from https://www.youtube.com/watch?v=RHfau6oRFhQ.

Chan, T-W., Roschelle, J., Hsi, S., Kinshuk, K., Sharples, M., Brown, T. et al., 2006, 'Oneto-one technology-enhanced learning: An opportunity for global research collaboration', Research and Practice in Technology Enhanced Learning 1(1), 3-29. https://doi.org/10.1142/S1793206806000032

Chang, Y.C., Peng, H.Y. \& Chao, H.C., 2010, 'Examining the effects of learning motivation and of course design in an instructional simulation game', Interactive Learning Environments 18(4), 319-339. https://doi.org/10.1080/10494820802574270

Chen, C.-H., Wang, K.-C. \& Lin, Y.-H., 2015, 'The comparison of solitary and collaborative modes of game-based learning on students' science learning and motivation', Educational Technology \& Society 18(2), 237-248.

Clark, D.B., Tanner-Smith, E.E. \& Killingsworth, S.S., 2016, 'Digital games, design, and learning: A systematic review and meta-analysis', Review of Educational Research 86(1), 79-122. https://doi.org/10.3102/0034654315582065

Cózar-Gutiérrez, R. \& Sáez-López, J.M., 2016, 'Game-based learning and gamification in initial teacher training in the social sciences: An experiment with MinecraftEdu', International Journal of Educational Technology in Higher Education 13(2), 11 pages. https://doi.org/10.1186/s41239-016-0003-4

Cubic Global Defence, 2015, Introducing game-based learning, YouTube video, viewed 07 November 2017, from https://www.youtube.com/watch?v=Hcy392vsxQw

D2L, 2016, Engage learners with game-based learning, YouTube Video, viewed 07 November 2017, from https://www.youtube.com/watch?v=KP9aRQ1zEAQ

Dickey, M.D., 2011, 'Murder on Grimm Isle: The impact of game narrative design in an educational game-based learning environment', British Journal of Educationa Technology 42(3), 456-469. https://doi.org/10.1111/j.1467-8535.2009.01032.x

Dizikes, P., 2013, 'The beer game: A rite of passage for new Sloan MBA students provides lessons in systems thinking', MIT Technology Review, viewed 12 November 2017, from https://www.technologyreview.com/s/520181/the-beergame/

Dror, I.E., 2005, 'Experts and technology: Do's and don'ts', Biometric Technology Today 13, 7-9. https://doi.org/10.1016/S0969-4765(05)70429-X

Dror, I.E., 2007, 'Gold mines and land mines in cognitive technology', Benjamins Current Topics 12, 1-7, viewed 01 January 2018, from https://www.researchgate. net/publication/242177151_Gold_mines_and_land_mines_in_cognitive_ technology. https://doi.org/10.1075/bct.12.02 $\mathrm{dro}$ 
Dror, I.E., 2010, 'Technology enhanced learning: The good, the bad, and the ugly', Inside Learning Technologies \& Skills December 2010, 79-84.

Ebner, M. \& Holzinger, A., 2007, 'Successful implementation of user-centered game based learning in higher education: An example from civil engineering', Computers \& Education 49, 873-890. https://doi.org/10.1016/j.compedu.2005.11.026

Fathers of the English Dominican Province, 2006, 'St. Thomas Aquinas, The Summa Theologica', viewed 01 January 2018, from http://www.documentacatholicaomnia. eu/03d/1225-1274, Thomas_Aquinas, Summa_Theologiae_\%5B1\%5D, EN.pdf

Gamelearn, 2014, What is game-based learning?, YouTube video, viewed 07 November 2017, from https://www.youtube.com/watch?v=Uj_8C2L9bXI

GLC (Global Learning Council), 2015, Technology-enhanced learning: Best practices and data sharing in higher education, Draft White Paper, viewed 01 January 2018, from http://globallearningcouncil.org/wp-content/uploads/2015/04/GLC_DRAFT White_Paper_April_2015.pdf

Goodyear, P. \& Retalis, S. (eds.), 2010, Technology-enhanced learning: Design patterns and pattern languages, vol. 2, Sense Publishers, Rotterdam, viewed 01 January 2018, from https://pdfs.semanticscholar.org/b2dd/d57d7e6ec3cb522e17655c38 fc6f15e22002.pdf

Gordon, N., 2014, Flexible pedagogies: Technology-enhanced learning, Higher Education Academy, viewed 10 May 2018, from https://www.heacademy.ac.uk/ system/files/resources/tel_report_0.pdf

Harris, K. \& Reid, D., 2005, 'The influence of virtual reality play on children's motivation', Canadian Journal of Occupational Therapy 72(1), 21-30. https://doi. org/10.1177/000841740507200107

Haskins, C.H., 1957, The rise of universities, Cornell University Press, New York.

Hess, T. \& Gunter, G., 2013, 'Serious game-based and nongame-based online courses: Learning experiences and outcomes', British Journal of Educational Technology 44(3), 22 pages.

Huang, W.-H., Huang, W.-Y. \& Tschopp, J., 2010, 'Sustaining iterative game playing processes in DGBL: The relationship between motivational processing and outcome processing', Computers \& Education 55, 789-797. https://doi.org/ 10.1016/j.compedu.2010.03.011

Hwang, G.-J., Sung, H.Y., Hung, C.M. \& Huang, I., 2012, 'Development of a personalized educational computer game based on students' learning styles', Educational Technology Research \& Development 60(4), 623-638. https://doi.org/10.1007/ s11423-012-9241-x

Hwang, G.-J. \& Tsai, C.C., 2011, 'Research trends in mobile and ubiquitous learning: A review of publications in selected journals from 2001 to 2010 ', British Journal of Educational Technology 42(4), E65-E70. https://doi.org/10.1111/j.1467-8535. 2011.01183.x

Hwang, G.-J. \& Wu, P.-H., 2012, 'Advancements and trends in digital game-based learning research: A review of publications in selected journals from 2001 to $2010 '$, British Journal of Educational
$\mathrm{org} / 10.1111 / \mathrm{j} .1467-8535.2011 .01242 . x$

Kiili, K., 2005, 'Digital game-based learning: Towards an experiential gaming model', Internet and Higher Education 8, 13-24. https://doi.org/10.1016/j.iheduc.2004. 12.001

Kikot, T., Costa, G., Fernandes, S. \& Águas, P., 2014, 'Why use-centered game-based learning in higher education? The case of Cesim Simbrand', Journal of Spatial and Organizational Dynamics 11(3), 229-241.

Kirkwood, A. \& Price, L., 2014, 'Technology-enhanced learning and teaching in higher education: What is "enhanced" and how do we know? A critical literature review', Learning, Media and Technology 39(1), 1-44. Handover version, viewed 06 December 2017, from http://oro.open.ac.uk/36675/1/TEL $\% 20$ in $\% 20 H i g h e r \%$ 20Education-What $\% 20$ is $\% 20$ enhanced $\% 20$ and $\% 20$ how $\% 20$ do $\% 20$ we $\% 20$ know.pdf

Kok, A., 2009, 'Understanding the technology enhanced learning environments from a cognitive perspective', International Education Studies 2(4), 3-9. https://doi. org/10.5539/ies.v2n4p3

Laurillard, D., 2002, Rethinking university teaching: A conversational framework for the effective use of learning technologies, Routledge/Falmer, New York.

Levin, R., 2015, 'A practical way to apply gamification in the classroom', e Learning Industry, viewed 07 November 2017, from https://elearningindustry.com/ practical-way-to-apply-gamification-in-the-classroom

Lin, Y.-L. \& Tu, Y.-Z., 2012, 'The values of college students in business simulation game: A means-end approach', Computers \& Education 58(4), 1160-1170. https://doi org/10.1016/j.compedu.2011.12.005

Liu, T.Y. \& Chu, Y.L., 2010, 'Using ubiquitous games in an English listening and speaking course: Impact on learning outcomes and motivation', Computers \& Education 55(2), 630-643. https://doi.org/10.1016/j.compedu.2010.02.023

Loughlin, G., 2009, 'Theology in the university', in I. Ker \& T. Merrigan (eds.), The Cambridge Companion to John Henry Newman, pp. 221-240, Cambridge University Press, Cambridge.

MacLellan, E. \& Soden, R., 2004, 'The importance of epistemic cognition in studentcentred learning', Instructional Science 32(3), 253-268.

Malone, T.W., 1980, 'What makes things fun to learn? Heuristics for designing instructional computer games', Proceedings of the 3rd ACM SIGSMALL symposium and the WRST SIGPC symposium on small system, ACM, New York, Septembe 18-19, 1980, pp. 162-169.

McGonigal, J., 2011, Reality is broken: Why games make us better and how they can change the world, Penguin, New York.

MIT (Massachusetts Institute of Technology), 2017, Supply chain forum, breakthrough research: Beer game, viewed 12 November 2017, from http://supplychain.mit. edu/supply-chain-games/beer-game/
Nadolny, L. \& Halabi, A., 2016, 'Student participation and achievement in a large lecture course with game-based learning', Learning Simulation \& Gaming 47(1), 51-72. https://doi.org/10.1177/1046878115620388

Oliver, E., 2017, 'Gamification as transformative assessment in higher education', HTS Theological Studies 73(3), a4527, 15 pages. https://doi.org/10.4102/hts. v73i3.4527

Papastergiou, M., 2009, 'Digital game-based learning in high school computer science education: Impact on educational effectiveness and student motivation', Computers \& Education 52(1), 1-12. https://doi.org/10.1016/j. compedu.2008.06.004

Pappas, C., 2015, Top gamification statistics and facts for 2015, viewed 01 January 2018, from https://elearningindustry.com/top-gamification-statistics-and-factsfor-2015

Pariser, E., 2011, The filter bubble: What the internet is hiding from you, Viking, London.

Prensky, M., 2001, Digital game-based learning, McGraw Hill, New York.

Rapti, K., 2013, 'Increasing motivation through gamification in e-learning', Proceedings of the 7th International Conference in Open \& Distance Learning, Athens, November 08-10, 2013, pp. 92-96.

Rashdall, H., 1936, The universities of Europe in the Middle Ages, vol. 1, SalernoBologna-Paris, Oxford University Press, London.

Richardson, N., 2005, 'The future of South African Theology: Scanning the road ahead', Scriptura 89, 550-562. https://doi.org/10.7833/89-0-1037

Rosenschine, B. \& Meister, C., 1992, 'The use of scaffolds for teaching high cognitive strategies', Educational Leadership 49(7), 26-33.

Ross, A.M., Fitzgerald, M.E. \& Rhodes, D.H., 2014, 'Game-based learning for systems engineering concepts', Procedia Computer Science 28, 430-440. https://doi. org/10.1016/j.procs.2014.03.053

See, C., 2016, Gamification for higher education, YouTube video, TEDxCUHK, viewed 07 November 2017, from https://www.youtube.com/watch?v=d8s3kZz1yQ4

Spector, J.M., Ifenthaler, D., Sampson, D., Yang, L., Mukama, E., Warusavitarana, A et al., 2016, 'Technology enhanced formative assessment for 21st century learning', Educational Technology \& Society 19(3), 58-71.

Spector, J.M. \& Anderson, T.M. (eds.), 2000, Integrated and holistic perspectives on learning, instruction and technology: Understanding complexity, Kluwer Academi Press, Dordrecht.

Sung, H.-Y. \& Hwang, G.-J., 2013, 'A collaborative game-based learning approach to improving students' learning performance in science courses', Computers \& Education 63, 43-51. https://doi.org/10.1016/j.compedu.2012.11.019

Taljaard, J., 2015, Game-based learning explained, YouTube video, viewed 12 June 2017, from https://www.youtube.com/watch?v=SumZ5FzjdSU.

Tang, S., Hanneghan, M. \& El-Rhalibi, A., 2009, 'Introduction to games-based learning', in T.M. Connolly M.H. Stansfield \& E. Boyle (eds.), Games-based learning advancement for multisensory human computer interfaces: Techniques and effective practices, pp. 1-17, Idea-Group Publishing, Hershey.

Taylor, T., 1801, The metaphysics of Aristotle, Davis, Wilks, \& Taylor, London.

Teachthought, 2014, We grow teachers: The difference between gamification and game-based learning, YouTube video, viewed 12 June 2017, from http://www. teachthought.com/learning/difference-gamification-game-based-learning/

TELRP (Technology Enhanced Learning Research Programme), 2013, Beyond prototypes: Enabling innovation in technology-enhanced learning, EPSRC viewed 08 May 2018, from http://tel.ioe.ac.uk/wp-content/uploads/2013/11/ BeyondPrototypes.pdf

Tracy, D., 2002, 'On theological education: A reflection', in R.L. Petersen \& N.M. Rourke (eds.), Theological literacy for the twenty-first century, pp. 13-22, Eerdmans, Grand Rapids, MI.

Tüzün, H., Yılmaz-Soylu, M., Karakus, T., Inal, Y. \& Kızılkaya, G., 2009, 'The effects of computer games on primary school students' achievement and motivation in geography learning', Computers \& Education 52(1), 68-77. https://doi. org/10.1016/j.compedu.2008.06.008

Van Eck, R.N., 2006, 'Digital game-based learning: It's not just the digital natives who are restless....', Educause Review 41(2), 1-16.

Van Eck, R.N., 2015, 'Digital game-based learning: Still restless after all these years', Educause Review 50(6), 13-28.

Vlachopoulos, D. \& Makri, A., 2017, 'The effect of games and simulations on higher education: A systematic literature review', International Journal of Educational Technology in Higher Education 14(22), 1-33. https://doi.org/10.1186/s41239 017-0062-1

Walker, R., Voce, J. \& Ahmed, J., 2012, 2012 Survey of technology enhanced learning for higher education in the UK, Universities and Colleges Information Systems Association, Oxford, viewed 06 December 2017, from http://www.ucisa.ac.uk/ groups/ssg/surveys.aspx

Wiggins, B. \& Simkowski, S., 2014, 'Game-based learning in higher education', in T. Bastiaens (ed.), Proceedings of World Conference on e-Learning, pp. 2050-2058, Association for the Advancement of Computing in Education (AACE), New Orleans, viewed 07 November 2017, from https://www.learntechlib.org/p/148764/

Woo, J.-C., 2014, 'Digital game-based learning supports student motivation, cognitive success, and performance outcomes', Educational Technology \& Society 17(3) 291-307.

Zichermann, G. \& Linder, J., 2010, Game-based marketing: Inspire customer loyalty through rewards, challenges, and contests, Wiley, Hoboken. 